\title{
Också Vilhelm Moberg fick sänkt sedebetyg
}

\section{Av Ingrid Nettervik, universitetslektor i svenska}

\author{
Länk till presentation av Ingrid Nettervik
}

Författarförlaget startade sin bokutgivning år 1970 med bland annat en nyutgåva av Vilhelm Mobergs roman Sänkt sedebetyg, den första delen i trilogin om Knut Toring. I förordet beskriver Moberg denna bok som sin första publikframgång. Den trycktes utgivningsåret 1935 i 12000 exemplar, vilket var mycket på den tiden, och boken blev något av en bestseller.

Man kan fråga sig vad framgången berodde på. Raskens (1927) fick ju ett gott mottagande av kritikerna men såldes de första åtta åren inte i mer än 4000 exemplar. Även romanerna om Adolf i Ulvaskog (Långt från landsvägen, 1929, och De knutna händerna,1930) håller god litterär kvalitet, men inte heller de blev någon försäljningssuccé. Kanske ligger förklaringen i att Sänkt sedebetyg är mer personligt hållen än någon av Mobergs tidigare böcker och att han har lagt in mer av sig själv än i föregångarna.

Den sistnämnda aspekten berör Moberg i sitt förord till nyutgåvan och medger att boken är självbiografisk i ett avseende:

\begin{abstract}
Den avspeglar min inre utveckling under min barndoms- och ungdomstid. Men huvudpersonen Knut Torings yttre levnadsomständigheter är inte mina. Han är bondpojke med jämförelsevis besuttna föräldrar, jag är född i ett soldattorp med en skröplig hundraårig stuga, där vi bodde nio personer i ett enda rum.
\end{abstract}

Vilhelm Moberg var soldatson och Knut Toring är bondeson, det är sant, men vad Moberg skriver här måste ändå tas med en nypa salt. Moberg föddes i ett soldattorp och tillbringade sina första levnadsår där, men 1907 flyttade familjen till ett sextondels mantal. Knekten blev hemmansägare och familjen steg socialt. Inte heller är uppgiften med de nio personerna i samma rum helt korrekt. I familjen Moberg föddes visserligen sju barn, men två dog vid späd ålder, det ena före Vilhelms födelse. Magnus von Platen konstaterar i sin levnadsteckning Den unge Vilhelm Moberg att Moberg aldrig kunde ha haft mer än fyra syskon omkring sig. Det är mycket nog, men Moberg överdriver alltså i sitt förord situationen med trångboddheten.

En jämförelse mellan Sänkt sedebetyg och de barndomsminnen som Moberg återger i Berättelser ur min levnad (1968) visar också att det finns betydligt fler överensstämmelser mellan Mobergs barndom och Knut Torings uppväxtförhållanden än de som kan hänföras till författarens inre utveckling. Låt oss göra en jämförelse!

Upplevelsen av döden i de tidiga barnaåren är en parallell. Moberg miste vid fem års ålder en yngre bror. Ungefär lika gammal är Knut när hans lillebror Sture dör. Han ligger helt stilla i sin säng en dag när Knut stolt kommer hem med några "ålkusor" som han har fångat i Gölabäcken. Han väntar sig beröm för sin fångst men ingen bryr sig om honom. Föräldrarna har annat att tänka på än att ge sin äldste son beröm. Gölabäcken, där Knut också snärjer gäddor, har för övrigt sin motsvarighet i Bjurbäcken, som flyter förbi platsen där soldattorpet låg och som i ett par av Mobergs romaner uppträder under sitt verkliga namn, dock inte i Sänkt sedebetyg. Vilhelm och hans äldre bror Hjalmar ägnade sig gärna åt gäddfiske i Bjurbäcken.

Läshungern och den oförstående omgivningen som förfäras över detta lyte är ett annat 
självbiografiskt inslag. Moberg berättar i Berättelser ur min levnad hur hans mor hade tapetserat förstukvisten med Aftonbladets följetongsbilaga men utan att ta hänsyn till den rätta ordningsföljden. Det var Jules Vernes roman Den hemlighetsfulla ön som den läshungrige ynglingen inte kunde få något riktigt sammanhang i. Moberg rev då ner tapeterna och lade avsnitten i rätt ordning. Tyvärr saknades slutet. Det fick han vänta med att läsa tills han senare kunde få tag i boken. Också Knut Torings mor tapetserar kökskvisten med tidningspapper som den läshungrige sonen river ner, dock utan att läsaren får veta mer än att det rörde sig om tidningspapper.

Knut Toring får en dag läsa i en tidning att Folkbildningsförbundet i Stockholm lånar ut ett vandringsbibliotek. Han rekvirerar detta, och när det äntligen kommer upptäcker han att det följer med lånejournaler som måste fyllas i. Vilhelm Moberg berättar samma historia i Berättelser ur min levnad, och båda ynglingarna löser problemet på samma sätt. De fyller själva i journalen med bybornas namn, och när dessa inte räcker till går de till kyrkogården och fyller journalen med namnen på gravstenarna. Två kronor för tjugo böcker kostar bokkalaset Knut Toring. Vilhelm Moberg berättar i Berättelser ur min levnad att han för vandringsbibliotekets fyrtiotal böcker fick betala tre kronor.

Lärarinnan som lånar den läshungrige ynglingen av sina egna böcker, läsningen av Bibeln som belönas med en hel krona och korrespondenskursen i modersmålet är ytterligare paralleller. Båda ynglingarna lämnar dessutom skolan med sänkt sedebetyg. I Vilhelm Mobergs fall var det inte så allvarligt som det låter. Magnus von Platen, som undersökt saken närmare, har funnit att samtliga pojkar i klassen fick sänkt sedebetyg det år då Moberg lämnade skolan.

I "Skolan i skogen" berättar Moberg om sin allra första lärare, en före detta knekt, som undervisade barnen om de tre viktiga skiljetecknen, "dä stora, dä halvstora och dä lella skeljetecknet". Samme lärare tycks Knut Toring möta första året i skolan, åtminstone att döma av undervisningen om de tre skiljetecknen som i romanen kallas för "dä lella, dä halvstora och dä stora". "Vid komma ska ni styre er lite, bara lite - så lång tid bara som det tar att blinka en gång", förmanar Knuts lärare. Verklighetens lärare säger så här: "När du sir dä lella skiljetecknet ska du styra dej lite grann, ett ögnableck bara. Inte så länge att du hinner andas."

Påvelsmåla skola, som Vilhelm Mobergs skola hette, låg "i kanten av ett flyakärr djupt inne i skogen". På ursprungsplatsen finns nu bara husgrunden kvar. Själva byggnaden har flyttats ut från skogen fram till byn och tar varje år emot mängder av turister som vill se hur Vilhelm Mobergs skola ser ut. Skolhuset i Sänkt sedebetyg beskrivs på ett sätt som överensstämmer med Påvelsmåla skola. Det ligger vid ett stort kärr och innehåller ett stort rum där undervisningen bedrivs och ett litet rum som är lärarens bostad.

Liksom Vilhelm Moberg fick Knut Toring efter det första skolåret en lärarinna i stället för den vresige gubben. Verklighetens lärarinna hette fröken Maja och blev liksom romanens fröken Hjärtkvist upprörd när hon upptäckte att pojkarna tuggade snus. Båda förbjöd de detta oskick och lät barnen gå fram till katedern och visa tänderna för henne varannan dag.

"I min roman Sänkt sedebetyg är min skolgångs upplevelser omsmälta till dikt och förvandlade till oigenkännlighet", skriver Vilhelm Moberg i "Skolan i skogen". Han har låtit skolhuset i skogen få två lärarinnor, "en hård och osympatisk, fröken Kamp, en mild och sympatisk, fröken Hjärtkvist". Den sistnämnda har han utrustat med de goda egenskaperna hos sin egen lärarinna. "Jag hade inte glömt att hon lånade böcker åt en lässvulten pojke, och att han lönade henne illa för det."

Uppbrottet från hembygden och bondemiljön är ytterligare något som Knut Toring och Vihelm Moberg har gemensamt. Knut Toring älskar byn Lidalycke men hatar att leva bland människorna där. Det enda som sprider ljus i hans inre är böckerna. De bidrar också till att ge honom den kunskap som han behöver för att komma bort från byn till den hägrande storstaden. 
Om Vilhelm Moberg vet vi att han i sin ungdom avstod från att emigrera till Amerika, som han hade tänkt, mot att att han fick gå på Grimslövs folkhögskola. Den kunskap han skaffade sig där hjälpte honom ut i världen. Han läste vidare och hade ambitionen att ta realen men hindrades av spanska sjukan som var nära att sätta stopp för hans liv. I stället blev han journalist. Det dröjde visserligen tills han kom till huvudstaden, men till sist hamnade han där (1929) och befann sig då i en likartad situation som Knut Toring. Moberg bodde i storstaden och hade den älskade hembygden på stort avstånd. Kanske fick han brev från mor Ida Charlotta hemma i Moshult som liknar dem som Knut får från Hilda Toring, kärkomna brev som Knut bär i rockfickan flera dagar efter deras ankomst, brev skrivna med krokiga linjer och stora bokstäver för viktiga ord som "Helsans Dyra Gåfva","Arbetet" och "Grödan". Hilda Toring är dessutom i likhet med Vilhelm Mobergs mor varmt religiös.

Knut Toring är visserligen inte en framgångsrik författare, vilket Vilhelm Moberg var på väg att bli när han skrev Sänkt sedebetyg, men han sysslar med litteratur, dock inte så att han skriver själv. Han är redaktör på veckotidningen Fristunden, som liknar Saxons eller någon annan av de förströelsetidskrifter där Moberg fick sina noveller och bygdeberättelser tryckta. Och liksom Vilhelm Moberg har Knut Toring som storstadsbo emellanåt problem med sömnen.

Ett viktigt inslag i romanen återstår att kommentera, kärleken. Den spelar en viktig roll för Knut Toring. Hans stora kärlek heter Ebba. Redan i småskolan känner han sig dragen till henne och hans händer vill röra vid hennes hår. Han rycker henne gärna i flätorna och sliter bort det blå flätbandet. Men också när han blir äldre lockas han av Ebbas hår. När han i minnet återvänder till en sådan synupplevelse blir språket nästan lyriskt:

Ebba hukar sig bland vinbärsbuskarna. Hennes bomullsklänning är urväxt, hon går barbent och hon har solbränt skinn på sina fylliga ben. Ljust skimrar hårets flätor mot de svarta klasarna på buskarna. Det är märkvärdigt - fast han är stor och tretton år, så vill han ännu röra vid hennes fläta, om han tordes.

Enligt egen utsago hade Moberg själv hela sitt liv känt sig mer dragen till kvinnor än till män, och som skolpojke hade han tyckt bäst om att prata med flickorna. Pojkarna retade honom för detta och kallade honom för "tösapojk", vilket gjorde honom generad. Trots sitt intresse för flickor var han nämligen på den tiden blyg för dessa varelser och vågade på sin höjd dra dem i flätorna.

När man nu ser hur starkt det självbiografiska inslaget är i Sänkt sedebetyg ligger det nära till hands att ana personliga upplevelser också bakom den starka och inlevelserika skildringen av Knuts och Ebbas kärlekshistoria. Det finns personer som med bestämdhet påstår sig veta vem verklighetens Ebba var. Att Moberg själv sagt sig tycka särskilt mycket om romanens kärleksskildring bevisar visserligen ingenting, men nog kan man försiktigt våga påstå att det förstärker misstanken om verklighetsbakgrund.

Hur det än förhåller sig med Ebba och verkligheten, så har vi i Ebba ett av Mobergs finaste kvinnoporträtt. Hon blir till något mer än den första kvinna som Knut får uppleva kärlekens fulla njutning med, som gav honom "kvinnans hemlighetsbräddade gåva". Hon förkroppsligar den sanna kvinnligheten sådan Knut (säkert i likhet med Moberg) uppfattar denna och blir symbolen för den jord ur vilken hon är sprungen. För Knut blir hon dessutom sinnebilden för det han svikit genom att lämna Lidalycke by och bosätta sig i huvudstaden. Man kan i Ebbas gestalt skönja konturerna av den arketypiska stora modern. "Hon var en jordens starka kvinna, och hon skulle stanna här och bli en duglig matmor och hustru och föda barn åt gårdens nye husbonde." Detta vet Knut och Ebba när de träffas sista gången, kvällen innan Ebba gifter sig med Knuts skolkamrat Helgo.

Det är åtrån till Ebba som får Knut att i hemlighet lära sig dansa. På loggolvet i dansens virvlar håller han henne för första gången i sin famn. Och den kvällen händer det ofattbara att Ebba bjuder upp Knut till den sista valsen som är flickornas fria val. I armkrok smyger de sig bort tillsammans från logen, och rötmånadsåskan som mullrat hotfullt tidigare under 
kvällen har avlägsnat sig och lämnat augustinatten varm och regntung. Säkert är det ingen tillfällighet att författaren valt just skördemånaden för detta första kärleksmöte mellan de unga. Det ger en inramning och sensuell förstärkning i sann vitalistisk anda. På slåtterängen stannar Ebba tätt intill Knut:

Hennes ögon är ett skimmer som eggar och förvirrar. Hennes läppar är väntande halvöppna, som beredda att sluta sig om något. Hon har fulla, blodglänsande läppar. Ebbas mun är för honom som en blomkrona, ännu till hälften sluten och döljande hemligheter på sin botten.

Mer än en eldig kyss blir det emellertid inte denna kväll, men det är för ögonblicket nog för Knut som känner att "En sällsam dörr hade öppnats för honom, när Ebbas läppar tog emot hans". Knut går som i yrsel när Ebba sprungit ifrån honom, och läsaren ser honom en stund senare sitta omtumlad på åkerrenen:

Jordens andedräkt omsvepte honom. På åkern gulnade korn och havre, och den mognande äringens dofter stack som söta kryddor i hans näsborrar. En vind kom farande - havrens vippor rasslade sakta och en rönnbuske på renen skakade av sig regnvattnets droppar.

Mer vitalistiskt sensuell kan en litterär 30-talsskildring knappast bli. Det skulle i så fall vara i utformningen av kulissen till den scen där kärlekens fullbordan utspelar sig. Naturligtvis sker detta på ett sädesfält, den havreåker som Knut slagit och där Ebba tagit upp efter honom:

Ur jordbädden under ynglingen och flickan väller dofterna av söta gräs och råa rötter, syrsans spel klingar ur havrestubben invid deras öron. Men omärkligt och utan ljud faller kvällsdaggen över havrelyckans ren.

Förklaringen till romanens stora framgång ligger kanske i den inlevelsrika och sensuella kärleksskildringen. Och kanske har den blivit så stark och övertygande för att den inspirerats av händelser i ungdomen. Men mer än hypotetiska antaganden kan dessa funderingar aldrig bli. På samma vis förhåller det sig med påståendet att Vilhelm Mobergs roman Sänkt sedebetyg och hela trilogin om Knut Toring (Sömnlös, 1937 och Giv oss jorden! 1939) på djupet handlar om den hemlängtan som plågade Vilhelm Moberg själv. Kanske lät han Knut Toring förverkliga den önskedröm han själv bar på, att bryta upp från storstaden och återvända till jorden och hembygden.

\section{$\underline{\text { Ingrid Nettervik }}$}

(Artikeln tidigare publicerad i Iris nr 2 1998) 